\title{
ДО ПИТАННЯ ДОЦІЛЬНОСТІ ЗАСТОСУВАННЯ МОДЕЛЬНОГО ПІДХОДУ В ДОСЛІДЖЕННІ ПРОЦЕСУ ПІДГОТОВКИ МАЙБУТНІХ ВІЙСЬКОВИХ ЛЬОТЧИКІВ ДО БОЙОВИХ ПОЛЬОТІВ
}

\author{
Невзоров Р. В. \\ кандидат педагогічних наук, \\ заступник начальника кафедри льотної експлуатачії $і$ бойового застосування літаків \\ Харківський національний університет Повітряних сил імені Івана Кожедуба \\ вул. Сумська, 77/79, Харків, Украӥна \\ orcid.org/0000-0003-1496-2465 \\ roman_nevzorov@ukr.net
}

\begin{abstract}
Ключові слова:
спосіб пізнання, модельне дослідження, педагогічна модель, фахова підготовка військових льотчиків, бойова підготовка.
\end{abstract}

Стаття відкриває дискурс навколо проблеми доцільності застосування модельного підходу якуніверсального загальнонаукового методу пізнання в дослідженні процесу підготовки майбутніх військових льотчиків до бойових польотів в ЗВО України. Простежена інституціональна еволюція моделювання в науці загалом і педагогіці зокрема; акцентовано на тому, що генеза цього наукового методу бере початок на рубежі XIX-XX ст. у сфері точних наук (передусім, математики та логіки) і лише з другої половини ХХ ст. він поширюється на інші сфери наукового знання, зокрема педагогіку. Досліджено, що завдяки значному науковому потенціалу i бурхливому розвитку інформаційних технологій моделювання активно увійшло до методологічної бази більшості сучасних наукових дисциплін; у педагогіці воно набуло статусу самостійного методологічного напряму й отримало назву «педагогічне моделювання» (як синонімічні використовуються терміни «модельне дослідження», «модельний підхід», метод моделювання» та іноді «наукове проектування»). Зміст вказаної дискусії пов’язаний із певним дисбалансом: у педагогічних дисертаційних дослідженнях українських авторів останніх 5 років моделі використовуються досить активно і дедалі частіше, тоді як у роботах із проблем військової педагогіки - значно менше і рідше. Автор вважає, що потенціал цього способу пізнання педагогічних явищ і процесів у цій галузі педагогіки явно недооцінений. Спираючись на попередні наукові дослідження педагогічного моделювання, на прикладі моделі процесу підготовки майбутніх військових льотчиків до бойових польотів, що розробляється в рамках дисертаційного докторського дослідження, автор переконливо доводить доцільність і актуальність застосування модельного підходу. Зазначено, що він найбільш оптимально підходить для вивчення частини освітнього процесу, якою, по суті, $є$ вказаний процес підготовки: по-перше, моделювання по природі є системою, по-друге, воно базується на фундаментальних поняттях педагогіки, по-третє, через орієнтування на вдосконалення окремих аспектів освітнього процесу, по-четверте, 3 огляду на можливість у його методологічних рамках вибрати вихідні умови відповідно авторського розуміння педагогічної задачі. 


\title{
TO QUESTION OF EXPEDIENCY OF APPLICATION OF MODEL APPROACH IN RESEARCH OF PROCESS OF PREPARATION OF FUTURE SOLDIERY PILOTS TO BATTLE FLIGHTS
}

\author{
Nevzorov R. V. \\ Candidate of Pedagogical Sciences, \\ Deputy Head of the Department of Flying Exploitation and Battle Application of Airplanes \\ Ivan Kozhedub Kharkiv National Air Force University \\ Sumy str., 77/79, Kharkiv, Ukraine \\ orcid.org/0000-0003-1496-2465 \\ roman_nevzorov@ukr.net
}

Key words:
method of cognition, model
research, pedagogical model,
professional preparation of
soldiery pilots, combat training.

\begin{abstract}
The article opens discussion round the problem of expediency of application of model approach, as an universal scientific method of cognition, in research of process of preparation of future soldiery pilots to battle flights in establishment of higher education of Ukraine. Traced institutional evolution of design in science on the whole and in pedagogics in particular; the accented attention is on that genesis of this scientific method takes beginning on the border of XIX-XX century in the sphere of exact sciences (foremost, mathematicians and logics) and only from the second half of XX of century he spreads to other spheres of scientific knowledge, in particular in pedagogics. Investigational, that due to considerable scientific potential and rapid development of information technologies of design actively entered the methodological base of most modern scientific disciplines; in pedagogics it purchased status of independent methodological direction and got the name "pedagogical design" (as the synonymous are used terms "model research", "model approach", "design method" and sometimes. The table of contents of the indicated discussion is related to the certain disbalance: in pedagogical dissertation researches of the Ukrainian authors 5 last the models are used actively enough and all more often, while in works from the problems of military pedagogics - far fewer and rarer. An author considers that potential of this method of cognition of the pedagogical phenomena and processes in this industry of pedagogics is obviously underestimated. Leaning on previous scientific researches of pedagogical design, on the example of model of process of preparation of future soldiery pilots to battle flights, that is developed within the framework of dissertation doctoral research, an author leads to expediency and actuality of application of model approach convincingly. It is marked that he most optimally befits for the study of part of educational process, that essentially is the indicated process of preparation: firstly - a design on nature is the system; secondly, it is based on the fundamental concepts of pedagogics; thirdly, through an orientation on perfection of separate aspects of educational process and in fourth times, in force the had opportunity in his methodological scopes to choose initial terms accordingly authorial understanding of pedagogical task.
\end{abstract}

Постановка проблеми. Найвиразнішими тенденціями розвитку соціально-гуманітарної галузі наукового знання останньої чверті XX - поч. XXI ст. є міждисциплінарна інтеграція та масове поширення системного підходу. Зокрема, сучасна педагогіка активно запозичує i використовує загальнонаукову методологічну базу та науковий апарат суміжних наук. Одним із таких способів пізнання $є$ модельний підхід (метод моде- лювання, модельне дослідження, іноді наукове проєктування). Визнаний авторитет в області філософії науки і наукового пізнання В. Штофф визначив моделювання як «специфічний засіб відображення людиною вивчаємих об'єктів за допомогою аналогів, «заступників» (моделей)» $[1$, с. 12]. Водночас Е. Лодатко зауважив, що моделювання є настільки ж важливим для педагогіки, як і складним інструментом пізнання: по-перше, 
воно прийшло в педагогіку з інших наукових дисциплін, по-друге, воно покликано описати нечіткі (неточні - P.H.) педагогічні поняття [2, с. 11].

Популярність методу моделювання у вітчизняній педагогічній науці зростає 3 року в рік. Здійснений автором аналіз великого масиву дисертаційних робіт із педагогіки 2015-2020 рр. українських авторів засвідчив, що принаймні в 70\% 3 них застосоване моделювання як спосіб пізнання предмета дослідження. Водночас у дисертаціях iз проблем військової педагогіки цей показник значно нижче - близько $30 \%$. Вважаємо, що потенціал цього наукового підходу мало використовується в зазначеній педагогічній галуззі.

Теоретичну базу і методологію використання моделювання в дослідженні явищ i процесів педагогічної дійсності заклали роботи В. Афанасьєва, А. Бабанського, В. Безпалько, А. Богатирьова, А. Братка, С. Бєшєнкова, М. Вартофського, Б. Глинського, А. Дахіна, Ю. Делімова, Т. Ільїной, Л. Ітельсона, Є. Заїр-Бек, Н. Кузьміной, А. Куракіна, Е. Лодатко, В. Монахова, Л. Новікової, I. Новик, І. Підласого, В. Свинаренко, А. Семенової, А. Циганова, В. Штоффа, В. Ясвіна та інших.

Проте спеціальних педагогічних досліджень, в яких би процес підготовки майбутніх військових льотчиків до бойових польотів був описаний за допомогою модельного підходу, поки що у вітчизняній науці бракує. Водночас він дає змогу систематизувати і виокремити найсуттєвіші складники системи такої підготовки й побудувати цей процес у науковому балансі між прикладними вимогами до сучасних військових льотчиків та новітньою теорією їх навчання.

Мета статті - обгрунтування доцільності застосування модельного підходу в дослідженні процесу підготовки майбутніх військових льотчиків до бойових польотів.

Виклад основного матеріалу дослідження. Термін «модель» (від франц. modèle, що восходить корінням до лат. modulus - «міра, аналог, зразок») вперше введений до наукового обігу на рубежі XIX-XX ст. математиками Е. Бельтрамі, Ф. Клейном та філософами Г. Фреге, Б. Расселом стосовно математичних явищ і математичної логіки [3, с. 200]. 3 цього часу моделювання набуло інституціонального статусу наукового методу, але використовувалось переважно в царині точних наук. Iз середини XX ст. почалися активні наукознавчі дослідження моделювання: був розкритий його пізнавальний потенціал, що сприяло становленню моделювання як загальновизнаного загальнонаукового (загальнологічного) методу; розвиток кібернетики та інформаційно-коммунікаційних технологій сприяв активному впровадженню модельного підходу в усі сфери наукового знання; відбулось становлення педагогічного моделювання (родоначальником останнього у східноєвропейській науковій традиції вважається В. Штофф). 3 цього приводу М. Омельяновський слушно зауважив: «Моделювання універсалізується і в певному сенсі стає синонімом пізнання, що виражає ті характерні риси сучасного його етапу, які пов'язані з єдністю суворих і несуворих (формалізованих і неформалізованих) прийомів, 3 єдністю неперервності процесу отримання нової інформації» [4, с. 292-293].

Класичне визначення моделі як способу педагогічного пізнання запропонував В. Штофф: «Модель - це подумки уявлена або матеріально реалізована система, яка, відбиваючи або відтворюючи об'єкт дослідження, здатна його заміщати так, що іiі вивчення дасть нам нову інформацію про цей об' єкт» [1, с. 12]. А. Новіков і Д. Новіков у найширшому значенні під науковою моделлю розуміють образ певної системи [5, с. 195-196].

Ототожнення наукової моделі із системою принципово важливо для нашого дослідження. Процес фахової підготовки майбутніх військових льотчиків до бойових польотів як складника освітнього процесу сучасної української вищої школи доцільно і потрібно розглядати в контексті конкретної дидактичної системи, що має власні педагогічні закономірності та умови, використовує специфічну методику навчання, спрямовану на певний спроектований педагогічний результат. У цьому сенсі застосування модельного підходу, на наше глибоке переконання, здатне якнайточніше описати особливості вказаного процесу та побудувати оптимальну, з теоретичної і практичної сторін, педагогічну модель його реалізації у ЗВО України.

В означеному контексті важливо зрозуміти науковознавчі особливості саме педагогічного моделювання. Так, А. Булатбаєва на основі аналізу широкого масиву наявних педагогічних моделей виділяє в структурі більшості з них такі змістовні блоки:

- блок цілепокладання (закладені в модель цінності, філософія та ймовірний результат (педагогічна мета));

- структурно-позиційний блок (структурно-логічна схема моделі 3 уточненими взаємозв'язками);

- концептуально-регламентаційний блок (методологія і принципи, на яких побудована модель);

- змістовно-організаційний блок (системоутворююча діяльність у рамках моделі та основний зміст функціонування іiі структурних компонентів);

- технологічний блок (методика основної діяльності в рамках моделі);

- результативний блок (кінцеві результати та їі діагностика, критерії оцінювання) [6, с. 45]. 
Теоретико-педагогічна модель процесу підготовки майбутніх військових льотчиків до бойових польотів, яку розробляє автор цієї статті в рамках докторського дисертаційного дослідження, цілком відповідає вищенаведеній структурі:

1) педагогічна мета - науково-теоретичне обгрунтування сучасної, ефективної та гнучкої системи забезпечення якісної підготовки військово-авіаційних кадрів для потреб Збройних сил України, з урахуванням рівня розвитку і передового світового досвіду військової авіації в мирних і воєнних умовах (блок цілепокладання);

2) надбудова моделі - освітньо-інформаційне середовище ЗВО; етапи фахової підготовки підготовчий, діяльнісний, оціночний; складники підготовки - загальнотеоретичне, спеціальне техніко-теоретичне та тактико-теоретичне навчання, тренажерна підготовка, фізичні та фізіологічні тренування, льотна підготовка (наземна і повітряна), психологічний тренінг; підходи - системний, компетентнісний, особисто орієнтований; методика навчання - теоретичне, тренажерне, льотно-тактичне; результат - формування професійно значимих компетенцій і психологічної готовності до бойової діяльності (структурно-позиційний блок);

3) підходи - системний (фахова підготовка розглядається як цілісна дидактична система), компетентнісний (фахова підготовка (від постановки педагогічних мети і цілей до оцінювання педагогічного результату) будується на основі формування професійно необхідних і значимих компетенцій), особисто орієнтований (весь процес підготовки орієнтований на розвиток особистості майбутнього військового пілота та його індивідуальні особливості) (концептуально-регламентаційний блок);

4) зміст навчання - теоретичне (фізика польотів, будова військових літаків, навігаційне, навідне та інше обладнання літаків, бойові комплекси, військово-авіаційні комп'ютерні системи тощо), тренажерне (на всіх видах сучасних авіаційних симуляторних комплексів) та льотно-тактичне (наземна і повітряна підготовка, імітування зіткнень із противником та інших бойових місій), поділене на три взаємопов'язаних етапи - підготовчий (діагностика інтелектуальної, психологічної, фізичної, фізіологічної та мотиваційної готовності курсанта до майбутньої професійної діяльності; первинна підготовка - теоретичне та загальновійськове навчання, технічна та тренажерна пропедевтика, початковий фізичний та психологічний тренінг), діяльнісний («занурення» у професію - оволодіння військово-авіаційною тактикою, повноцінна тренажерна та льотна підготовка, імітування військових польотів у найрізноманітніших умовах; формування професійно значимих вмінь і навичок; відсів слабких курсантів) та оціночний (діагностика сформованості професійних компетенцій; остаточний відсів за ознакою фахової невідповідності) (змістовно-організаційний блок);

5) методика льотного навчання i конкретно-специфічна освітня програма (технологічний блок);

6) педагогічний результат - формування професійних бойових компетенцій військового льотчика - кадрового офіцера Повітряних сил 3С України, діагностично підтверджених на основі спеціальної шкали оцінювання (результативний блок).

Така структура моделі дає чітко описати всі складники процесу фахової підготовки, скласти детальний алгоритм навчання та зіставити його 3 існуючою професіограмою спеціальності, спроєктувати результат, методику і дидактичний інструментарій, а також грунтовно порівняти ії з результатами перевірочного експерименту та своєчасно внести необхідні корективи. При цьому така педагогічна модель $\epsilon$ доволі гнучкою, а пї валідність відносно високою.

На користь доцільності застосування методу моделювання для пізнання піднятої проблеми говорять й інші аргументи. Зокрема, М. Ядровська справедливо вказує на те, що педагогічні моделі завжди базуються на фундаментальних поняттях педагогіки - освіті, вихованні та навчанні, а отже, завжди спрямовані на дослідження об'єкта і предмета крізь призму процесу освіти 3 метою вдосконалення окремих аспектів останнього [7, с. 139]. Процес підготовки майбутніх військових льотчиків до бойових польотів якраз $є$ частиною освітнього процесу, в якому чітко присутні як навчальна (власне фахова підготовка), так і виховна (психологічна готовність до виконання бойових завдань, патріотизм і здатність до самовіддачі та самопожертви) складники, а наукове пізнання цього педагогічного конструкту продиктоване метою його вдосконалення для досягнення соціально значимих результатів і запитів до української армії в умовах гібридної війни і реального військового конфлікту.

Висновки. 3 огляду на багатофакторність педагогічної системи, що моделюється і цілком підпадає під дію логічних теорем К. Геделя про неповноту і непротирічливість формальних систем, застосування модельного підходу у вивченні нашого предмета дослідження видається нам найвдалішим методологічним вибором. Дослідник отримує змогу самостійно відібрати початкові (вихідні) умови залежно від власного розуміння задач, що особливо актуально для процесу фахової підготовки військових пілотів у ЗВО, яка тривалий час залишається незмінною і не відпо- 
відає сучасним соціально-економічним, науково-технічним та військово-тактичним вимогам.

Зважаючи на доволі низький рівень використання цього способу пізнання в сучасній вітчизняній військово-педагогічній науці, з одного боку, та доволі істотний рівень загальної наукознавчої розробленості педагогічного моделювання як методологічного інструмента - 3 іншого, вбачаємо перспективними подальші дослідження в цій науковій сфері.

\section{Література}

1. Штофф В.А. Моделирование и философия. Москва : Наука, 1966. 301 с.

2. Лодатко Є.О. Моделювання в педагогіці: точки відліку. Педагогічна наука: історія, теорія, практика, тенденції розвитку : е-журнал. 2010. Вип. № 1. URL: http://intellect-invest.org.ua/pedagog editions_e-magazine_pedagogical (дата звернення: 24.08.2020)

3. Федотова О.С. Когнитивное моделирование как метод познания и изучения объекта в научных исследованиях. Филологические науки. Вопросы теории и практики. 2015. № 4. Ч. 2. С. 199-202.

4. Материалистическая диалектика и методы естественных наук : сборник статей / ред. М.Э. Омельяновского. Москва : Наука, 1968. 608 с.

5. Новиков А.М., Новиков Д.А. Методология научных исследований. Москва : Либроком. 2010. 280 с.

6. Булатбаева А.А. Метод моделирования в исследовательской деятельности магистранта. Вестник КазНУ. Серия «Педагогические науки». 2013. № 2 (39). С. $42-47$.

7. Ядровская М.В. Модели и моделирование в педагогике. Ростов-на-Дону, 2014. 358 с.

\section{References}

1. Shtoff, V.A. (1966) Modelirovanie i filosofiya [Design and philosophy]. Moscow: Science. 301 p.

2. Lodatko, Y.O. (2010) Modelyuvannya $\mathrm{v}$ pedahohitsi: tochky vidliku [Design in pedagogics: points of counting out]. Pedagogical science: history, theory, practice, progress trends: e-magazine. Vol. 1. URL: $\mathrm{http} / / /$ intellect-invest.org.ua/pedagog_editions_e- magazine_pedagogical

3. Fedotova, O.S. (2015) Kognitivnoe modelirovanie kak metod poznaniya i izucheniya objekta v nauchnyh issledovaniyah [Cognitive design as a method of cognition and study of object is in scientific researches]. Philological sciences. Questions of theory and practice. Vol. 4. P. 199-202.

4. Omelyanovskij, M.E. (1966) Materialisticheskaya dialektika i metody estestvennyx nauk: sbornik statej [Materialistic dialectics and methods of natural sciences]. Moscow : Science. 608 p.

5. Novikov, A.M., Novikov, D.A. (2010) Metodologiya nauchnyx issledovanij [Methodology of scientific researches]. Moscow : Librocom. 280 p.

6. Bulatbaeva, A.A. (2013) Metod modelirovaniya $v$ issledovatelskoj deyatelnosti magistranta [A design method is in research activity of postgraduates]. Announcer of the KazNU. Series are "Pedagogical sciences". Vol. 2 (39). P. 42-47.

7. Jadrovskaja, M.V. (2014) Modeli i modelirovanie v pedagogike [Models and design are in pedagogics]. Rostov-on-Don. P. 358. 